Egypt. Acad. J. Biolog. Sci., 11(1): 33- 47 (2019)

Egyptian Academic Journal of Biological Sciences

D. Histology \& Histochemistry

$2090-0775$

www.eajbsd.journals.ekb.eg

\title{
Effect of Moringa Leaves Extract on Some Metabolic and Biochemical Alterations in Induced Type 2 Diabetes Male Albino Rats.
}

\author{
Dalia W. Zeidan', Mohamed T. A. Soliman²,Seham A. Helmy ${ }^{3,4}$, Hala M. Ebaid ${ }^{5}$ \\ and Heba M. A. Abdelrazek ${ }^{* *}$ \\ 1-Department of Home and Economics, Nutrition and Food Science Branch, Faculty \\ of Education, Suez Canal University, Egypt \\ 2-College of Applied Medical Sciences, Department of Medical Laboratory Sciences, \\ University of Bisha, Bisha 61922, p.o. Box 551, Kingdom of Saudi Arabia. \\ 3-Department of Cytology and Histology, Faculty of Veterinary Medicine, Suez \\ Canal University, Ismailia, Egypt. \\ 4-Department of Nursing, College of Applied Medical Sciences, University of Bisha, \\ Bisha 61922, p.o. Box 551, Kingdom of Saudi Arabia. \\ 5-Department of Zoology, Faculty of Science, Suez Canal University, Ismailia, Egypt \\ 6-Department of Physiology, Faculty of Veterinary Medicine, Suez Canal University, \\ Ismailia 41522, Egypt \\ E. Mail.: hebaabdelrazekvet@gmail.com
}

ARTICLE INFO

Article History

Received: 25/1/2019

Accepted: 29/3//2019

\section{Keywords:}

Type 2 diabetes, Moringa extract, rat, insulin resistance, TNF- $\alpha$

\section{ABSTRACT}

Type 2 diabetes is associated with bad health consequences. The current study focused on the effect of Moringa olifera $(M O)$ extract on some metabolic and biochemical parameters in induced type 2 diabetic albino rats. Twenty-eight albino male rats were selected and randomly divided into 4 groups. The control rats fed on a standard balanced diet and the second group fed standard balanced diet and gavaged with MO extract 50 $\mathrm{mg} / \mathrm{kg}$ b.wt. The third group was a diabetic group that was induced to type 2 diabetes by high dietary fat for 8 weeks followed by streptozotocin (STZ) $25 \mathrm{mg} / \mathrm{kg}$ intraperitoneal (i.p.) while the fourth group was induced to type 2 diabetes and gavaged with $\mathrm{MO}$ extract $50 \mathrm{mg} / \mathrm{kg}$ b.wt. Treatment was continued for 4 weeks and, final body weight was recorded. Serum Lipid Profile, insulin resistance, super oxide dismutase (SOD), tumor necrosis factor alpha $(T N F-\alpha)$, resistin and liver enzymes were determined. Histopathology to hepatic tissue was also done. Results revealed a significant reduction in final body weights of diabetic rats than control. Serum lipid profile was deteriorated in the diabetic group. Insulin resistance, TNF- $\alpha$, resistin and liver enzymes were significantly upregulated $(\mathrm{P}<0.05)$ in the diabetic rats than control while SOD was significantly reduced $(\mathrm{P}<0.05)$. Liver histopathology showed diffuse hazy vacuolation with leukocytic infiltration in the diabetic group and estrogen receptor (ER) immunostaining was significantly declined in diabetic group. All these changes were ameliorated with MO extract administration to diabetic rats. MO extract has a potential preventive effect against metabolic and biochemical alterations of type 2 diabetes. 


\section{INTRODUCTION}

Type 2 diabetes is widely spread worldwide disease (Shaw et al., 2010). It is closely associated with insulin resistance and obesity (Guilherme et al., 2008). This disease is characterized by impairments in physiological body processes such as altering pancreatic function and secretion as well as metabolic disorders including glucose, protein and lipid (Tabak et al., 2009). This disease is characterized by hyperglycemia and dyslipidemia (Guo et al., 2018; Vinson and Zhang, 2005).

It usually associated with disturbed insulin function and activity those results in prolonged hyperglycemia that promotes oxidative stress. The later causes dramatic perturbations in the liver (Loria et al., 2013), eyes (Lutty, 2013), kidneys, bone tissue (Moseley, 2012), immune system (Wright et al., 2006), nervous tissue (Lue et al., 2012), and other parts of the body (King and Rosenthal, 2015).

Animal models are good instruments for studying anti-diabetic therapeutic agents (Luo et al., 1998). A novel Type 2 diabetes model has gained popularity in the last few years. It developed by feeding laboratory animals with a high-fat diet to produce insulin resistance, then low -dose streptozotocin (STZ) was injected (25 $\mathrm{mg} / \mathrm{kg}$ i.p.) to result in slight pancreatic $\beta$-cells dysfunction without impairing insulin secretion completely. This animal model resembles closely the development of the natural Type 2 diabetes including its metabolic criteria (Watts et al., 2005), Therefore, this model has been used for researching the mechanisms involved in Type 2 diabetes and assessing its potential therapies (Shatwan et al., 2013).

Antioxidants have been used as a strategy for the treatment of diabetes.
Many herbal plants, as well as their extract or derivatives, are useful for the treatment of metabolic syndrome and diabetes with high antioxidant activity (Abdelrazek et al., 2018; Kasetti et al., 2010; Ramesh et al., 2012; Ramesh et al., 2015).They also overcome the adverse effects of pharmacological chemical agents (Ramesh et al., 2012).

Moringa oleifera (MO) is a traditional herbal plant that has been used for a long time as a food ingredient or in traditional folk medicine (Thurber and Fahey, 2009). There is a wide range of $\mathrm{MO}$ pharmacological actions like thyroid hormone regulator, antihypertensive, laxatives, anti-diabetic and antibiotics (Anwar et al., 2007; Fahey, 2005; Taweerutchana et al., 2017). The administration of MO has been associated with glucose homeostasis inside the body (Kar et al., 2003; Makonnen et al., 1997; Ndong et al., 2007). In addition, MO is well known to have estrogenic ingredients that could exert estrogen-like action on its receptors (Bose, 2007; Shukla et al., 1988). Estrogen and its receptors have a dramatic role in fat deposition and metabolism (Cooke and Naaz, 2004) ER are potentially expressed in adipocytes where it performs regulatory functions (AbdelRazek et al., 2013).

The aim of this study is to investigate the effect of Moringa olifera leaves extract on some metabolic and biochemical parameters (lipid profile, tumor necrosis factor alpha (TNF- $\alpha$ ) and resistin production, oxidative stress in relation to insulin resistance as well as liver enzymes) in induced type 2 diabetic albino rats.

\section{MATERIALS AND METHODS Animals and Animals Care:}

A total of 28 adult male albino rats weighing 120-135 g were bought 
from the National Research Centre Laboratory Animal House, Giza, Egypt. They were left to be acclimatized for 10 days before the beginning of the experiment. Animals were maintained at room temperature around $\left(25 \pm 2{ }^{\circ} \mathrm{C}\right)$. They were allowed to free access for water and standard rodent diet. The protocols of this study were approved and conducted according to the ethical guidelines for the use of animals in laboratory experiments of the Faculty of Veterinary Medicine, Suez Canal University, Egypt.

Moringa oleifera Extract Preparation:

Moringa oleifera aqueous extract was prepared according to Tuorkey (2016) by mixing $10 \mathrm{~g}$ of dried powdered leaves of MO with $100 \mathrm{~mL}$ of distilled water for $24 \mathrm{~h}$ and then stored at $4{ }^{\circ} \mathrm{C}$. Afterward, the mixture was filtered two times by using a $2-\mu \mathrm{m}$ pore filter paper. The stock solution of this aqueous extract $(100 \mathrm{mg} / \mathrm{mL})$ was kept prepared as a fresh solution for each set of experiment.

\section{Induction of Diabetes:}

Diabetes type 2 was induced to rats according to Guo et al. (2018). Rats were given high-fat diet for 8 weeks to induce insulin resistance then they were administered $25 \mathrm{mg} \mathrm{STZ} \mathrm{/}$ $\mathrm{kg}$ i.p. in cold citrate buffer PH 7.4 after $16 \mathrm{~h}$ fasting. The composition of experimental diets was followed as mentioned by Guo et al. (2018).

\section{Experimental Design:}

Rats were grouped randomly into 4 groups ( 7 rats each). The control rats fed on a standard balanced diet, the second group controlled MO group that fed standard balanced diet and given MO extract $50 \mathrm{mg} / \mathrm{kg}$ via gavage. The third group was a diabetic group that was induced to type 2 diabetes while the fourth group was diabetic MO group, they were induced to type 2 diabetes and given $\mathrm{MO}$ extract $50 \mathrm{mg} / \mathrm{kg}$ via gavage the treatment was continued for 4 weeks.

\section{Final Body Weight:}

Final body weights were recorded at the end of the experimental period to all rats.

\section{Blood Sampling:}

After 4 weeks of experimentation, fasted overnight rats were anaesthetized and euthanized. Blood samples were collected in plain tubes. Samples were left for $15 \mathrm{~min}$. to clot and kept in the fridge for $3 \mathrm{hrs}$ then centrifuged at $3000 \mathrm{rpm}$ for 20 $\min$. The obtained sera were stored at $30{ }^{\circ} \mathrm{C}$ for liver enzyme and lipid profile assays.

\section{Serum Lipid Profile:}

Kits were obtained from Biodiagnostic Co., Egypt, estimated serum levels of total cholesterol (TC), triglycerides (TG) and high-density lipoprotein cholesterol (HDL) calorimetrically. Low-density lipoproteins were calculated according to Davidson and Rosenson (2009) as follow: LDL-C = Total Cholesterol(Triglycerides/5 +HDL-Cholesterol).

\section{Homeostasis Model Assessment- Estimated Insulin Resistance (HOMA-IR):}

After overnight fasting, blood glucose levels of the experimental rats were determined via glucometer (Accu-Chek Active, Germany). Serum insulin levels were estimated using commercial rat specific ELISA kits (Abnova, Germany) according to the manufacturer's instructions. According to Matthews et al. (1985), HOMA-IR was calculated by the following formula:

HOMA-IR = fasting insulin $(\mathrm{U} / \mathrm{L}) \times$ fasting glucose $(\mathrm{mg} / \mathrm{dL}) / 405$.

Super Oxide Dismutase (SOD) and Tumor Necrosis Factor Alpha (TNF$\alpha)$ :

Serum level of SOD was determined using a commercial kit (Oxis Research, USA). Serum level of 
TNF- $\alpha$ was determined using a commercial ELISA kit (Code No. 27194, IBL Co., and Japan). Both measured according to the enclosed manufacturer's instructions.

\section{Serum Resistin and Liver Enzymes:}

Resistin levels were determined using commercial specific ELISA kit (BioVendor Co., Czech) according to enclosed pamphlet protocol. The activity of liver enzymes as aspartate aminotransferase (AST) and alanine aminotransferase (ALT) were measured by a colorimetric method using Diamond Diagnostic Kits (Egypt).

Histopathology

and immunohistochemistry:

Livers and epididymal fat were excised then immersed in $10 \%$ formalin solution for 24 hours. They were processed for routine histopathological protocol mentioned by Drury and Wallington (1980). Livers sections were stained with hematoxylin and eosin (H\&E) and examined under a light microscope.

The paraffin-embedded fat tissues were cut into $5 \mu \mathrm{m}$ sections on positively charged slides for ER immunohistochemistry. Dewaxing and antigen retrieval were done by boiling with citrate buffer (PH 6)10 Mm. the procedures were followed according to AbdelRazek et al. (2013) using ER primary monoclonal antibody (\# MS750-R7-A, Thermo Fisher Scientific, USA). Image analysis for immunohistochemistry stained parts was done via image J program. Six random fields were selected for each rat / group and subjected to image analysis to calculate immunohistochemistry stained area \% (IHCSA\%).

\section{Statistical Analysis:}

All values were expressed as the mean \pm standard error (SE) of the mean. The differences among groups were analyzed using Graph Pad Prism (Version 5.01, Graph Pad Software, San Diego, USA) using one-way analysis of variance (ANOVA) followed by post hoc which is Tukey's test for inter-group comparisons A probability $<0.05$ is considered significantly differed.

\section{RESULTS}

\section{Final Body Weight:}

The final body weights of experimental rats were shown in Fig. 1. The diabetic rats exhibited significantly $(\mathrm{P}<0.05)$ reduced final body weights than control. Control MO group and MO treated diabetic one showed significant $\quad(\mathrm{P}<0.05)$ decline in final body weight of rats than control however both were significantly $(\mathrm{P}<0.05)$ promoted than a diabetic group.

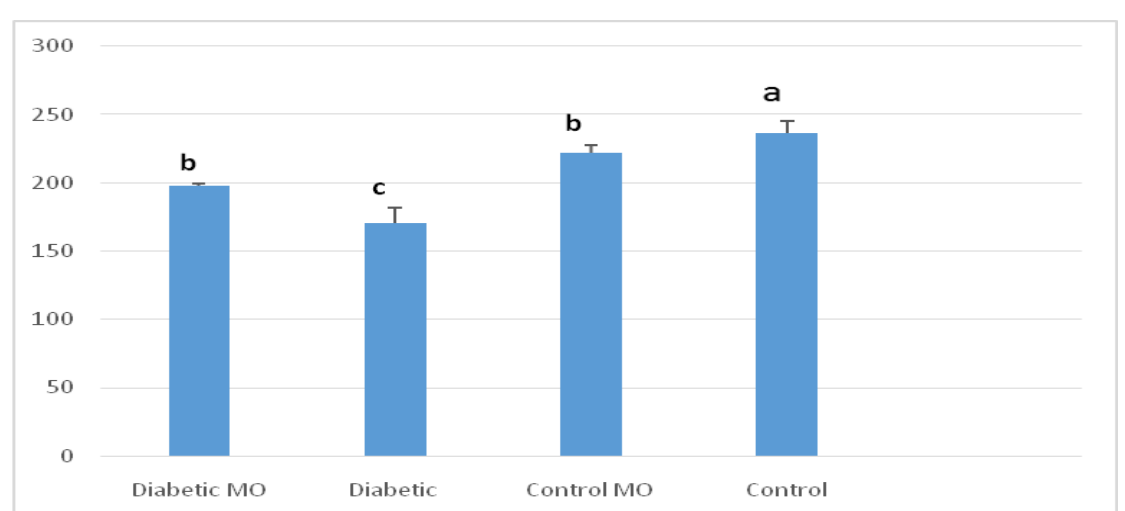

Fig. 1: Effect MO leaves extract on final body weights of type 2 induced diabetic male Albino rats.

Different superscripts between bars are considered significant at $\mathrm{P}<0.05$. 


\section{Lipid Profile:}

The levels of TG, TC and LDL were significantly $(\mathrm{P}<0.05)$ increased in the diabetic group than control. The administration of MO extract to diabetic rats significantly declined $(\mathrm{P}<0.05)$ the levels of the later parameters than the diabetic group to a level comparable to control. The HDL level was significantly decreased $(\mathrm{P}<0.05)$ in the diabetic group than control. The treatment of diabetic rats with $\mathrm{MO}$ significantly $\quad(\mathrm{P}<0.05)$ promoted the HDL levels than the diabetic group (Table 1).

\section{HOMA-IR:}

Table 1 demonstrated that insulin resistance was significantly promoted $(\mathrm{P}<0.05)$ in the diabetic group than control. MO extract treatment to diabetic rats significantly $(\mathrm{P}<0.05)$ ameliorated $(\mathrm{P}<0.05)$ the elevated insulin resistance in the diabetic group.
Super Oxide Dismutase (SOD) and Tumor Necrosis Factor Alpha (TNF- $\alpha$ ): The diabetic group revealed significantly $(\mathrm{P}<0.05)$ reduced the serum level of SOD than control. The treatment of the diabetic group with MO extract significantly restored the SOD reduction. On the other side, TNF- $\alpha$ was significantly $(\mathrm{P}<0.05)$ elevated in the diabetic group than control one. The administration of MO to diabetic group reduced the elevated TNF- $\alpha$ levels caused by diabetes (Table 2).

\section{Serum Resistin and Liver Enzymes:}

Table 2 revealed that diabetic rats had elevated liver enzymes (ALT and AST) as well as resistin levels $(\mathrm{P}<0.05)$ than control. The MO extract administration significantly ameliorated the elevated values of AST, ALT and resistin levels than the diabetic group.

Table 1: Effect of MO extract on lipid profile, HOMA-IR and TNF- $\alpha$ level in Type 2 induced diabetic male Albino rats

\begin{tabular}{|l|l|l|l|l|}
\hline & \multicolumn{1}{|c|}{ Control } & \multicolumn{1}{|c|}{ Control MO } & \multicolumn{1}{|c|}{ Diabetic } & Diabetic MO \\
\hline TG(mg/dL) & $65.32 \pm 2.67^{\mathrm{a}}$ & $54.93 \pm 2.62^{\mathrm{a}}$ & $104.30 \pm 3.03^{\mathrm{b}}$ & $86.67 \pm 2.76^{\mathrm{c}}$ \\
\hline TC $(\mathrm{mg} / \mathrm{dL})$ & $86.59 \pm 2.73^{\mathrm{a}}$ & $71.44 \pm 3.04 \mathrm{ac}$ & $141.30 \pm 11.50^{\mathrm{b}}$ & $95.22 \pm 2.90^{\mathrm{ac}}$ \\
\hline HDL $(\mathrm{mg} / \mathrm{dL})$ & $46.60 \pm 1.30^{\mathrm{a}}$ & $50.46 \pm 0.72^{\mathrm{a}}$ & $31.41 \pm 1.72^{\mathrm{b}}$ & $39.47 \pm 0.38^{\mathrm{c}}$ \\
\hline LDL $(\mathrm{mg} / \mathrm{dL})$ & $120.10 \pm 3.20^{\mathrm{a}}$ & $110.90 \pm 1.89 \mathrm{a}^{\mathrm{c}}$ & $151.90 \pm 11.24^{\mathrm{b}}$ & $117.40 \pm 2.73^{\mathrm{ac}}$ \\
\hline HOMA-IR & $0.27 \pm 0.01^{\mathrm{a}}$ & $0.26 \pm 0.01^{\mathrm{ac}}$ & $0.43 \pm 0.04 \mathrm{~b}$ & $0.30 \pm 0.003^{\mathrm{ac}}$ \\
\hline
\end{tabular}

Different superscripts between columns are considered significant at $\mathrm{P}<0.05$.

Table 2: Effect of MO extract on serum ALT, AST, resistin and TNF- $\alpha$, levels in Type 2 induced diabetic male Albino rats

\begin{tabular}{|l|l|l|l|l|}
\hline & Control & Control MO & Diabetic & Diabetic MO \\
\hline SOD U/mL & $4.89 \pm 0.09^{\mathrm{a}}$ & $5.32 \pm 0.36^{\mathrm{a}}$ & $2.36 \pm 0.34^{\mathrm{c}}$ & $3.87 \pm 0.17 \mathrm{~d}$ \\
\hline ALT (U/L) & $26.9 \pm 1.86^{\mathrm{a}}$ & $20.8 \pm 0.75^{\mathrm{a}}$ & $60.92 \pm 1.64^{\mathrm{b}}$ & $38.32 \pm 1.55^{\mathrm{c}}$ \\
\hline AST (U/L) & $51.27 \pm 1.50^{\mathrm{a}}$ & $44.23 \pm 2.29^{\mathrm{a}}$ & $86.43 \pm 6.41^{\mathrm{b}}$ & $70.42 \pm 2.55^{\mathrm{c}}$ \\
\hline Resistin $(\mathrm{ng} / \mathrm{mL})$ & $3.53 \pm 0.38^{\mathrm{a}}$ & $3.17 \pm 0.12 \mathrm{a}$ & $7.13 \pm 0.16 \mathrm{~b}$ & $4.54 \pm 0.22 \mathrm{c}$ \\
\hline TNF- $\alpha(\mathrm{pg} / \mathrm{mL})$ & $6.46 \pm 0.19^{\mathrm{a}}$ & $6.3 \pm 0.06^{\mathrm{a}}$ & $17.6 \pm 0.75^{\mathrm{b}}$ & $11.74 \pm 0.47^{\mathrm{c}}$ \\
\hline
\end{tabular}

Different superscripts between columns are considered significant at $\mathrm{P}<0.05$. 


\section{Histopathology:}

The hepatic architecture of both control and Moringa olifera (MO) extract treated control groups were showing normal hepatic lobules with eosinophilic hepatocytes which arranged in cords around the central vein. The hepatic cords separated from each other by blood sinusoids, which contained kupffer cells. The blood sinusoids showed moderate dilatation in MO group (Figs. 2a\&b).

Diabetic group was showing histopathological changes represented by, diffuse hazy vacuolation in the hepatocytes and marked dilatation in the blood sinusoids with hyperplasia in the kupffer cells. Also, the focal area of leukocytic aggregation was observed with thin early fibrous tissue proliferation. The portal triad showed marked enlarged portal vein with parts of desquamation in the endothelium. Thickening and hyalinization in the wall of the portal vein and the bile duct were also observed (Fig. 2c,d\&e). The diabetic group treated with MO extract displayed dramatic amelioration to diabetes, appeared as mild vacuolar degeneration, slight congestion in the central vein without fibrosis or leukocytic infiltration (Fig. 2f).

Immunohistochemistry:

Immunohistochemistry for ER demonstrated higher $(\mathrm{P}<0.05)$ IHCSA\% in MO control followed by control group than the diabetic ones. Treatment of experimentally induced diabetic rats with MO extract significantly promoted IHCSA\% than the diabetic group (Fig. 3). 

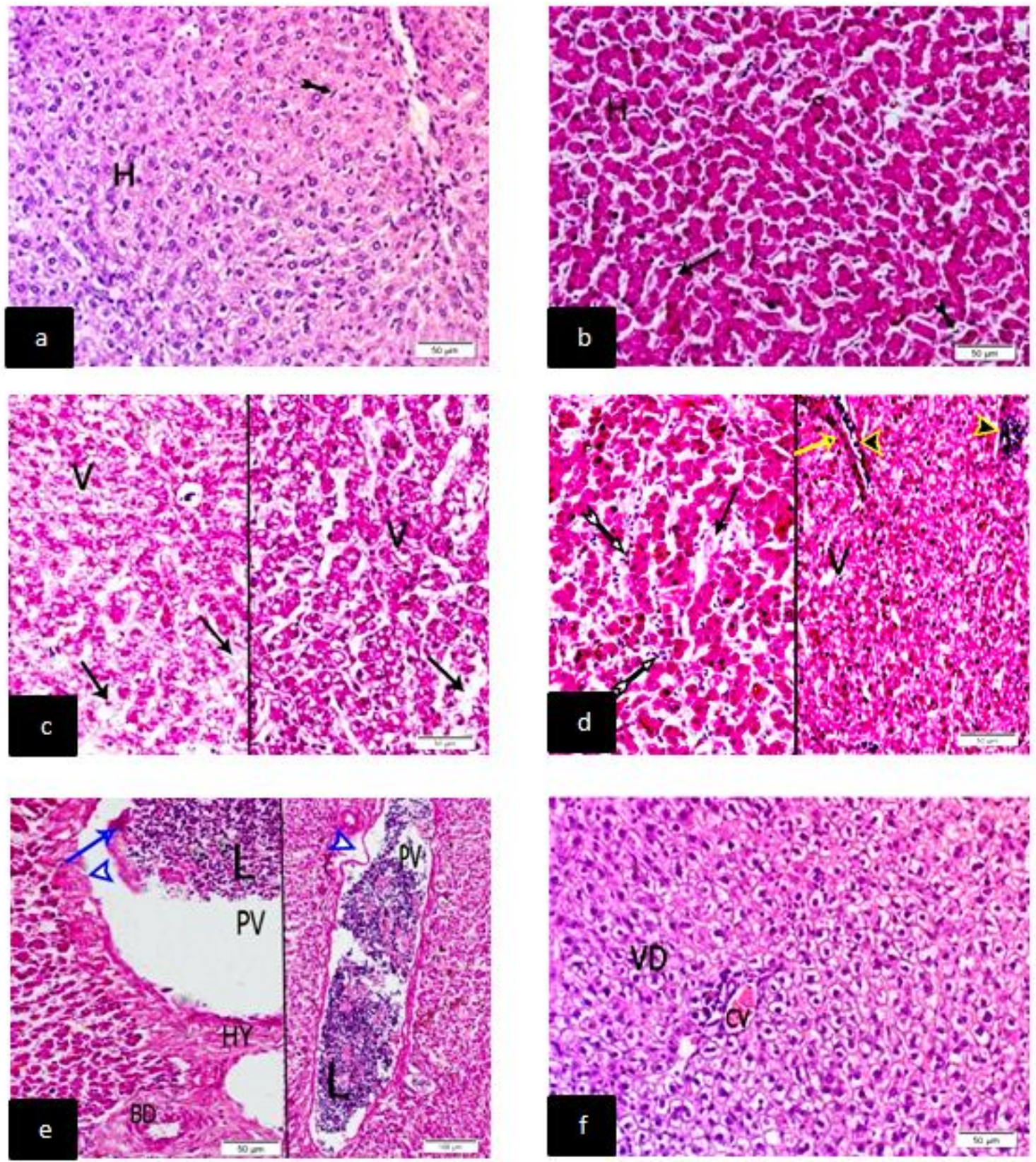

Fig. 2 Photomicrographs of liver stained with H\&E. Control rats (a) and Moringa olifera (MO) extract $50 \mathrm{mg} / \mathrm{kg}$ treated liver (b): showed the normal structure of the liver represented by normal hepatic cords and eosinophilic hepatocytes $(\mathrm{H})$, blood sinusoids (straight black arrow) and kupffer cells (tailed arrow). Diabetic group (c,d) showed diffuse hazy vacuolation in the hepatocytes (V), dilatation in the blood sinusoids (straight black arrow), hyperplasia in the kupffer cells (tailed white arrow) along with focal leukocytic aggregation (head black arrow) and thin early fibrous tissue proliferation (straight yellow arrow). (e): marked enlarged portal vein (PV), desquamation in the endothelium (head white arrow), Thickening, and hyalinization in the wall of the portal vein and the bile duct (HY). The diabetic group treated with MO extract group (f): showed mild vacuolar degeneration (VD) and slight congestion in the central vein (CV). 

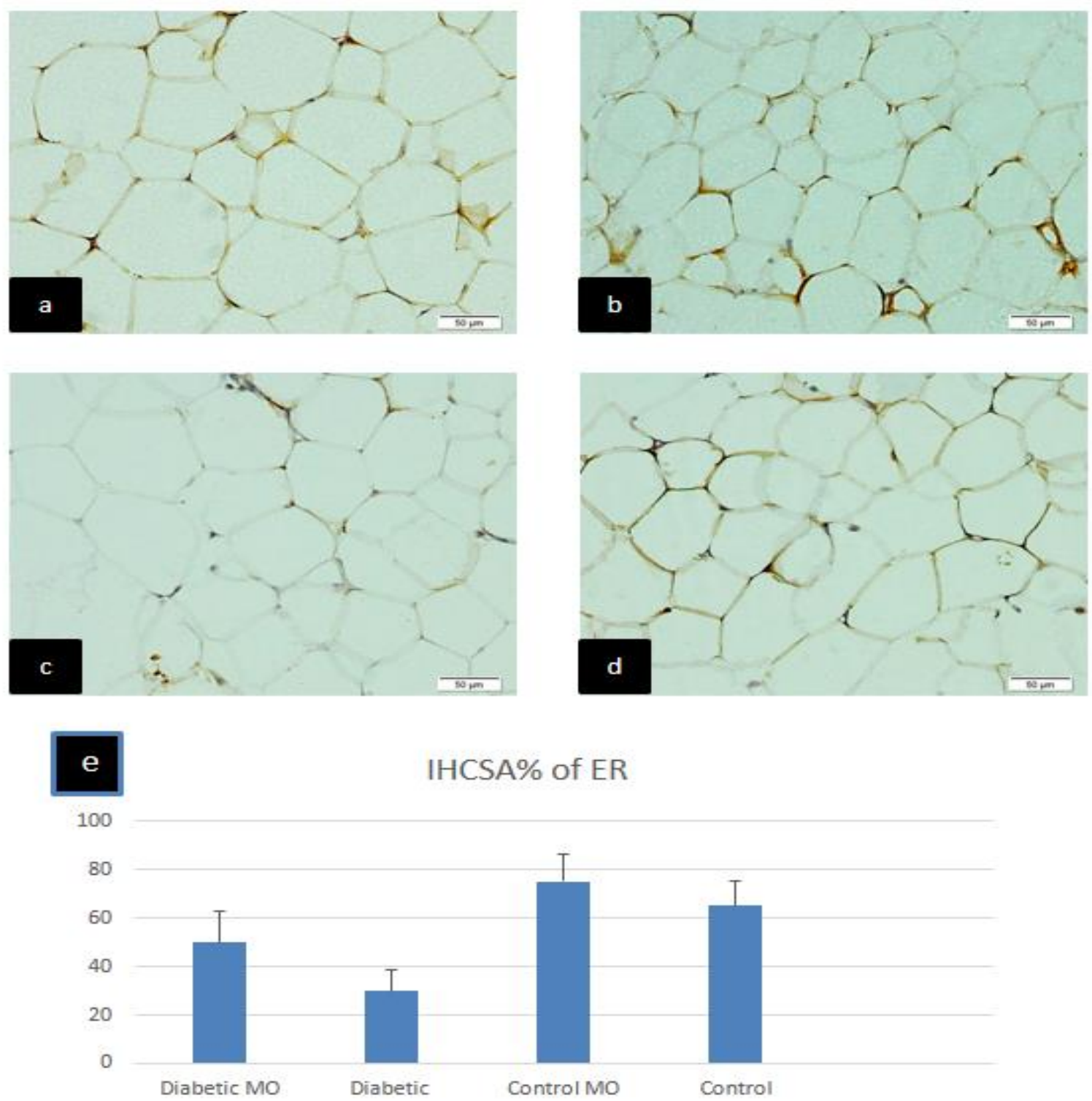

Fig. 3 showed the effect of MO extract on the expression of ER in epididymal fat. The control (a) and MO control fats (b) exhibited higher immunostaining affinity than diabetic rats (C). the administration of Mo extract to diabetic rats elevated the immunostaining affinity in this group (d) than diabetic group. The IHCSA\% was decreased in diabetic rats than control and MO while administration of MO significantly improved IHCSA\% than the diabetic group (e). Different superscripts between bars are considered significant at $\mathrm{P}<0.05$. 


\section{DISCUSSION}

The present study investigated the therapeutic potential of $\mathrm{MO}$ in counteracting the adverse consequences of Type 2 diabetes in Albino rats. As observed in this study, diabetes significantly reduced the final body weight of animals, meanwhile, the initial weights for all groups are nonsignificant, that concord with results of Villarruel-López et al. (2018) and Abdelrazek et al. (2018). The reduction of final body weight was attributed to muscle wastages due to lack of glucose entry to cells as well as amino acids thus creating a biosynthetic deficit in muscles(Wong and Tzeng, 1993).The administration of MO extract $50 \mathrm{mg} / \mathrm{kg}$ to diabetic rats significantly promoted this weight loss. This was in agreement with Olayaki et al. (2015) and Villarruel-López et al. (2018). The weight increment in this group may be due to blood glucose lowering the effect of Mo explained by reduced insulin resistance in such group(Olayaki et al., 2015; Villarruel-López et al., 2018). This allows biosynthetic ability of muscles. Also, MO leaves shown nutritive values as they contain vitamins, minerals and amino acids (Olayaki et al., 2015).

Diabetes caused lipid profile perturbations where TG, TC and LDL were significantly elevated while HDL was declined. These results concord with Doğan and Çelik (2016) and Guo et al. (2018). Observed dyslipidemia due to excessive lipolysis caused via hypoglycemia that increased lipid parameters level in blood with abnormal metabolism (Horrobin, 1988). MO showed hypolipidemic effect in diabetic rats that was parallel to previous results of Tété-Bénissan et al. (2013). MO is well known to have polyphenols, a potent natural antioxidants that could ameliorate dyslipidemia (Rajanandh et al., 2012). Moreover, MO contains plant sterols that are able to reduce blood cholesterol level through LDL lowering effect via inhibiting the reabsorption of cholesterol as well as increasing its excretion in the form of neutral steroids through feces(Ghasi et al., 2000).

The induction of type 2 diabetes resulted in increased insulin resistance that agreed with (Dupas et al., 2016). HOMA0-IR is a good indicator for tissues sensitivity especially the liver to produce insulin (Carnevale Schianca et al., 2006). MO extract potentially decreased diabetic insulin resistance. Our data was in harmony with those of Tuorkey (2016), who attributed this effect to the antioxidant and antihyperglycemic capabilities of MO extract leaves that enable it to recover insulin resistance.

The activity of SOD was significantly depleted in the diabetic group than control while TNF- $\alpha$ was significantly increased, these effects were ameliorated by giving MO extract to diabetic rats. These results were in accordance with those of Omodanisi et al. (2017b). SOD is an enzymatic antioxidant that considered the first line of defense against oxygen-derived free radicals where it makes dismutation of superoxide radicals to water (McCune and Johns, 2002). It is logic that diabetes depleted the SOD level due to increased ROS resulted from hyperglycemia. The amelioration of SOD level in the diabetic group by MO may be related to the active ingredient of this extract like phenols and terpenoids (Vergara-Jimenez et al., 2017). TNF- $\alpha$ is very important cytokine that recognized as a mediator for tissue defense, pro-inflammation and injury that is mediated by macrophages. Also, it has a role in cell proliferation and apoptosis (Pober and Min, 2006). This pro-inflammatory cytokine has role in impeding insulin signaling and 
implicated in insulin resistance (Grimble, 2002). Moreover, it is closely linked to the presence of diabetesinduced oxidative stress (Sudharshana Murthy et al., 2018) thus ameliorated by the antioxidant ingredients of $\mathrm{MO}$ extract.

Resistin hormone is produced from adipose tissue and implements a crucial role in the induction of insulin resistance (Rajala et al., 2003). The induction of type 2 diabetes in this study promoted a higher level of serum resistin that reduced by $\mathrm{MO}$ administration. Our results were in harmony with (Metwally et al., 2017). This can explain the ability of Mo to reduce adipocytes power to produce resistin through its active ingredients especially estrogenic compounds as well as $\beta$-sitosterol (Makkar and Becker, 1996).

Serum levels of AST and ALT were significantly elevated in the diabetic group than control that was ameliorated by MO. These results were partially consistent with Omodanisi et al. (2017a). The liver is a central organ that is involved in glucose homeostasis and supplies glucose as an energy source to other organs. Induction of diabetes that produced hyperglycemia and insulin resistance are a causal factor for hepatic damage that reflected by increased hepatocellular injury markers ALT and AST. These enzymes are usually found in hepatocytes. Elevation of their levels is an indicator for hepatic membrane injury caused by diabetic oxidative stress (Harper, 1979). This is clear in the histopathological picture where diffuse hepatocytes vacuolation along with focal leucocytes and thin early fibrous tissue proliferation. The administration of MO extract that is known for its hypolipidemic and hypoglycemic as well as anti-oxidant effect is responsible for amelioration of the hepatic injury to mild vacuolar degeneration with a reduction in ALT and AST (Omodanisi et al., 2017a).

This IHCSA\% of ER in the diabetic group showed significant decrease than control. This result is consistent with the lipid profile abnormalities and elevated insulin resistance observed in such a group. Estrogen through interplay with ER exerts a substantial role in lipid metabolism, glucose uptake and deposition of fat (Blüher, 2009; Blüher, 2013). MO seems to have an estrogenic effect by promoting ER in epididymal fat of diabetic rats thus ameliorated diabetic dyslipidemia and insulin resistance.

In conclusion, the induction of type 2 diabetes resulted in serious changes in body weight, lipid profile, insulin resistance, oxidative stress and liver tissue. Administration of MO to diabetic rats ameliorated all the adverse effects of diabetes via modulation of insulin resistance, oxidative stress and TNF- $\alpha$.

\section{REFERENCES}

Abdelrazek, H., Kilany, O.E., Muhammad, M.A., Tag, H.M., and Abdelazim, A.M. (2018). Black seed thymoquinone improved insulin secretion, hepatic glycogen storage, and oxidative stress in streptozotocin-induced diabetic male wistar rats. Oxidative medicineand cellular longevity 2018.

AbdelRazek, H.M.A., Tag, H.M., Tantawy, H.M., and Thabet, H. (2013). Soy isoflavones reduce adiposity via increasing estrogen receptor beta expression in ovariectomized female rats. . Egypt Acad J Biolog Sci 5, 59 -71.

Anwar ,F., Latif, S., Ashraf, M., and Gilani, A.H. (2007). Moringa oleifera: a food plant with multiple medicinal uses. Phytotherapy Research: An International Journal Devoted to Pharmacological and 
Toxicological Evaluation of Natural Product Derivatives 21, 17.25-

Blüher, M. (2009). Adipose tissue dysfunction in obesity. Experimental and Clinical Endocrinology \& Diabetes 117, 241-250.

Blüher, M. (2013). Importance of estrogen receptors in adipose tissue function. Molecular metabolism 2, 130.

Bose, C.K .(2007) .Possible role of Moringa oleifera Lam. root in epithelial ovarian cancer. MedGenMed : Medscape general medicine 9, 26-26.

Carnevale Schianca, G.P., Sainaghi, P.P., Castello, L., Rapetti, R., Limoncini, A.M., and Bartoli, E. (2006). Comparison between HOMA-IR and ISI-gly in detecting subjects with the metabolic syndrome. Diabetes/metabolism research and reviews 22, 111-117.

Cooke, P.S., and Naaz, A. (2004). Role of estrogens in adipocyte development and function. Experimental biology and medicine 229, 112.1135-7

Davidson, M.H., and Rosenson, R.S. (2009). Novel targets that affect high-density lipoprotein metabolism: the next frontier. The American journal of cardiology 104, 52E-57E.

Doğan, A., and Çelik, İ. (2016). Healing effects of sumac (Rhus coriaria)in streptozotocin-induced diabetic rats. Pharmaceutical biology 54, 20922102.

Drury, R., and Wallington, E. (1980). Preparation and fixation of tissues. Carleton's histological technique 5, 41-54.

Dupas, J., Goanvec, C., Feray, A., Guernec, A., Alain, C ,Guerrero, F., and Mansourati, J. (2016). Progressive Induction of Type 2 Diabetes: Effects of a Reality-Like Fructose Enriched Diet in Young
Wistar Rats. PloS one 11, e0146821-e0146821.

Fahey, J.W. (2005). Moringa oleifera: a review of the medical evidence for its nutritional, therapeutic, and prophylactic properties. Part 1 . Trees for life Journal 1, 1-15.

Ghasi, S., Nwobodo, E., and Ofili, J. (2000). Hypocholesterolemic effects of crude extract of leaf of Moringa oleifera Lam in high-fat diet fed Wistar rats. Journal of Ethnopharmacology 69, 21-25.

Grimble, R.F. (2002). Inflammatory status and insulin resistance. Current Opinion in Clinical Nutrition \& Metabolic Care 5, 551-559.

Guilherme, A., Virbasius, J.V., Puri, V., and Czech, M.P. (2008). Adipocyte dysfunctions linking obesity to insulin resistance and type 2 diabetes. Nature reviews Molecular cell biology 9, 367-377.

Guo, X.-X., Wang, Y., Wang, K., Ji, B.P., and Zhou, F. (2018). Stability of a type 2 diabetes rat model induced by high-fat dietfeeding with lowdose streptozotocin injection. Journal of Zhejiang University Science B 19, 559-569.

Harper, C. (1979). Wernicke's encephalopathy: a more common disease than realised. A neuropathological study of 51 cases. Journal of Neurology, Neurosurgery \& Psychiatry 42, 226-231.

Horrobin, D. (1988). The roles of essential fatty acids in the development of diabetic neuropathy and other complications of diabetes mellitus. Prostaglandins, leukotrienes, and essential fatty acids 31, 181-197.

Kar, A., Choudhary, B., and Bandyopadhyay, N. (2003). Comparative evaluation of hypoglycaemic activity of some Indian medicinal plants in alloxan diabetic rats. Journal of ethnopharmacology 84, 105-108. 
Kasetti, R.B., Rajasekhar, M.D., Kondeti, V.K., Fatima, S.S., Kumar, E.G.T., Swapna, S., Ramesh, B., and Rao, C.A. (2010). Antihyperglycemic and antihyperlipidemic activities of methanol: water $(4: 1)$ fraction isolated from aqueous extract of Syzygium alternifolium seeds in streptozotocin induced diabetic rats. Foodand Chemical Toxicology 48, 1078-1084.

King, K.B., and Rosenthal, A.K. (2015). The adverse effects of diabetes on osteoarthritis: update on clinical evidence and molecular mechanisms. Osteoarthritis and cartilage 23, 841-850.

Loria, P., Lonardo, A., and Anania, F. (2013). Liver and diabetes. A vicious circle. Hepatology research : the official journal of the Japan Society of Hepatology 43, 51-64.

Lue, L.-F., Andrade, C., Sabbagh, M., and Walker, D. (2012). Is There Inflammatory Synergy in Type II DiabetesMellitus and Alzheimer's Disease? International journal of Alzheimer's disease 2012, 918680918680.

Luo, J., Quan, J., Tsai, J., Hobensack, C.K., Sullivan, C., Hector, R., and Reaven, G.M. (1998). Nongenetic mouse models of non-insulindependent diabetesmellitus. Metabolism: clinical and experimental 47, 663-668.

Lutty, G.A. (2013). Effects of diabetes on the eye. Investigative ophthalmology \& visual science 54 , ORSF81-ORSF87.

Makkar, H.a., and Becker, K. (1996). Nutrional value and antinutritional components of whole and ethanol extracted Moringa oleifera leaves. Animal feed science and technology 63, 211-228.

Makonnen, E., Hunde, A., and Damecha, G. (1997). Hypoglycaemic effect of Moringa stenopetala aqueous extract in rabbits. Phytotherapy Research :An International Journal Devoted to Medical and Scientific Research on Plants and Plant Products 11, 147148.

Matthews, D.R., Hosker, J.P., Rudenski, A.S., Naylor, B.A., Treacher, D.F., and Turner, R.C. (1985). Homeostasis model assessment: insulin resistance and beta-cell function from fasting plasma glucose and insulin concentrations in man. Diabetologia 28, 412-419.

McCune, L.M., and Johns, T. (2002). Antioxidant activity in medicinal plants associated with the symptoms of diabetes mellitus used by theindigenous peoples of the North American boreal forest. J Ethnopharmacol 82, 197-205.

Metwally, F.M., Rashad, H.M., Ahmed, H.H., Mahmoud, A.A., Abdol Raouf, E.R., and Abdalla, A.M. (2017). Molecular mechanisms of the anti-obesity potential effect of Moringa oleifera in the experimental model. Asian Pacific Journal of Tropical Biomedicine 7, 214-221.

Moseley, K.F. (2012). Type 2 diabetes and bone fractures. Current opinion in endocrinology, diabetes, and obesity 19, 128-135.

Ndong, M., Uehara, M., Katsumata, S., and Suzuki, K. (2007). Effects of Oral Administration of Moringa oleifera Lam on Glucose Tolerance in Goto-Kakizaki and Wistar Rats. Journal of clinical biochemistry and nutrition 40, 229-233.

Olayaki, L.A., Irekpita, J.E., Yakubu, M.T., and Ojo ,O.O. (2015). Methanolic extract of Moringa oleifera leaves improves glucose tolerance, glycogen synthesis and lipid metabolism in alloxan-induced diabetic rats. Journal of basic and clinical physiology and pharmacology 26, 585-593. 
Omodanisi, E.I., Aboua ,Y.G., Chegou, N.N., and Oguntibeju, O.O. (2017a). Hepatoprotective,

Antihyperlipidemic, and Antiinflammatory Activity of Moringa oleifera in Diabetic-induced Damage in Male Wistar Rats. Pharmacognosy research 9, 182187.

Omodanisi, E.I., Aboua, Y.G., and Oguntibeju, O.O. (2017b). Assessment of the AntiHyperglycaemic, Anti-Inflammatory and Antioxidant Activities of the Methanol Extract of Moringa Oleifera in Diabetes-Induced Nephrotoxic Male Wistar Rats. Molecules (Basel, Switzerland) 22, 439.

Pober, J ,.and Min, W. (2006). Endothelial cell dysfunction, injury and death. In The Vascular Endothelium II (Springer), pp. 135156.

Rajala, M.W., Obici, S., Scherer, P.E., and Rossetti, L. (2003). Adiposederived resistin and gut-derived resistin-like molecule- $\beta$ selectively impair insulin action on glucose production. The Journal of clinical investigation 111, 225-230.

Rajanandh, M., Satishkumar, M., Elango, K., and Suresh, B. (2012). Moringa oleifera Lam. A herbal medicine for hyperlipidemia: A preclinical report. Asian Pacific Journal of Tropical Disease 2, S790-S795.

Ramesh, B., Karuna, R., Sreenivasa, R.S., Haritha, K., Sai, M.D., Sasis, B.R.B., and Saralakumari, D. (2012). Effect of Commiphora mukul gum resin on hepatic marker enzymes, lipid peroxidationand antioxidants status in pancreas and heart of streptozotocin induced diabetic rats. Asian Pacific journal of tropical biomedicine 2, 895-900.

Ramesh, B., Sainath, S., Karuna, R., Reddy, S.S., Manjunatha, B., Sudhakara, G., Rao, B.S.B., and
Saralakumari ,D. (2015). Effect of Commiphora mukul gum resin on hepatic and renal marker enzymes, lipid peroxidation and antioxidants status in pancreas and heart in fructose fed insulin resistant rats. Beni-Suef University Journal of Basic and Applied Sciences 4, 2-69 .278

Samad, A., Shams, M., Ullah, Z., Wais, M., Nazish, I., Sultana, Y., and Aqil, M. (2009). Status of herbal medicines in the treatment of diabetes: a review. Current diabetes reviews 5, 102-111.

Shatwan, I.A., Ahmed, L.A., and Badkook, M.M .(2013) .Effect of barley flour, crude cinnamon, and their combination on glycemia, dyslipidemia, and adipose tissue hormones in type 2 diabetic rats. Journal of medicinal food 16, 656662.

Shaw, J.E., Sicree, R.A., and Zimmet, P.Z. (2010). Global estimates of theprevalence of diabetes for 2010 and 2030. Diabetes research and clinical practice $87,4-14$.

Shukla, S., Mathur, R., and Prakash, A.O. (1988). Antifertility profile of the aqueous extract of Moringa oleifera roots. Journal of Ethnopharmacology 22, 51-62.

Sudharshana Murthy, K.A., Bhandiwada, A., Chandan, S.L., Gowda, S.L., and Sindhusree, G. (2018). Evaluation of Oxidative Stress and Proinflammatory Cytokines in Gestational Diabetes Mellitus and Their Correlation with Pregnancy Outcome. Indian journal ofendocrinology and metabolism 22, 79-84.

Tabak, A.G., Jokela, M., Akbaraly, T.N., Brunner, E.J., Kivimaki, M., and Witte, D.R. (2009). Trajectories of glycaemia, insulin sensitivity, and insulin secretion before diagnosis of type 2 diabetes: an analysis from the 
Whitehall II study. Lancet (London, England) 373, 2215-2221.

Tag, H.M., Abdelazek, H.M., Mahoud, Y.S., and EL-Shenawy, N.S. (2015). Efficacy of Tribulus terrestris extract and metformin on fertility indices and oxidative stress of testicular tissuein streptozotocininduced diabetic male rats. African Journal of Pharmacy and Pharmacology 9, 1088-1098.

Taweerutchana, R., Lumlerdkij, N., Vannasaeng, S., Akarasereenont, P., and Sriwijitkamol, A. (2017). Effect of Moringa oleifera Leaf Capsules on Glycemic Control in TherapyNaïve Type 2 Diabetes Patients: A Randomized Placebo Controlled Study. Evidence-based complementary and alternative medicine : eCAM 2017, 65813906581390.

Tété-Bénissan, A., Quashie, M.A., Lawson-Evi, K., Gnandi, K., Kokou, K., andGbeassor, M. (2013). Influence of Moringa Oleifera leaves on atherogenic lipids and glycaemia evolution in HIV-infected and uninfected malnourished patients. Journal of Applied Biosciences 62, 4610-4619.

Thurber, M.D., and Fahey, J.W. (2009). Adoption ofMoringa oleifera to combat under-nutrition viewed through the lens of the "Diffusion of innovations" theory. Ecology of food and nutrition 48, 212-225.

Tuorkey, M.J. (2016). Effects of Moringa oleifera aqueous leaf extract in alloxan induced diabetic mice. Interventional Medicine and Applied Science 8, 109-117.

Vergara-Jimenez, M., Almatrafi, M.M., and Fernandez, M.L. (2017).
Bioactive Components in Moringa Oleifera Leaves Protect against Chronic Disease. Antioxidants (Basel, Switzerland) 6, 91.

Villarruel-López, A., López-de la Mora, D.A., Vázquez-Paulino, O.D., Puebla-Mora, A.G., Torres-Vitela, M.R., Guerrero-Quiroz, L.A., and Nuño, K. (2018). Effect of Moringa oleifera consumption on diabetic rats. BMC complementary and alternative medicine $18,127-12.7$

Vinson, J.A., and Zhang, J. (2005). Black and green teas equally inhibit diabetic cataracts in a streptozotocin-induced rat model of diabetes. Journal of agricultural and food chemistry 53, 3710-3713.

Watts, L.M., Manchem, V.P., Leedom, T.A., Rivard, A.L., McKay, R.A., Bao, D., Neroladakis, T., Monia, B.P., Bodenmiller, D.M., Cao, J.X., et al. (2005). Reduction of hepatic and adipose tissue glucocorticoid receptor expression with antisense oligonucleotides improves hyperglycemia and hyperlipidemia in diabetic rodents without causing systemic glucocorticoid antagonism. Diabetes 54, 1846-1853.

Wong, K., and Tzeng, E. (1993). Appearance of different diabetic symptoms after streptozocin administration: a comparison study. Biochemistry and molecular biologyinternational 30, 1035-1041.

Wright, E., Jr., Scism-Bacon, J.L., and Glass, L.C. (2006). Oxidative stress in type 2 diabetes: the role of fasting and postprandial glycaemia. International journal of clinical practice $60,308-314$ 


\section{ARABIC SUMMARY}

تأثير مستخلص أوراق المور ينجا على التغيرات الأيضية والكيميائية الحيوية الناجمة عن مرض السكري من النوع الثاني المستحدث في ذلات النور الجرذان البيضاء

داليا وحيد زيدان 1 ،محمد طلعت سليمان2، سهام عباس حلمي 3،4 هالة محمد عبيد5، هبة محمد عبد الرازق6 6

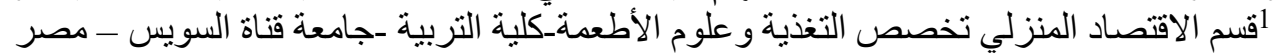

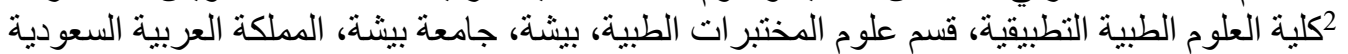

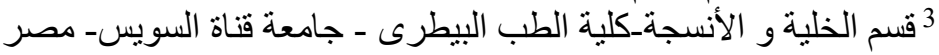

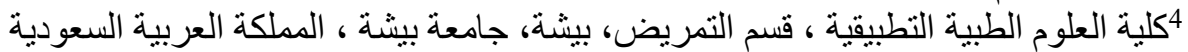

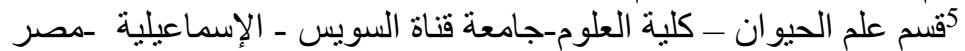

6قسم الفيسيولوجيا_كلية الطب البيطري -جامعة قناة السويس ـالإسماعيلية ـمصر الإعلية

يرتبط داء السكري من النوع الثاني بآثار جانبية صحية سيئة. ركزت الثياء الدراسة الحالية على تأثنير

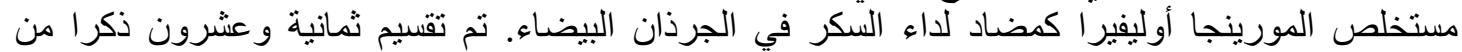

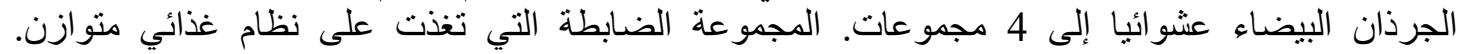

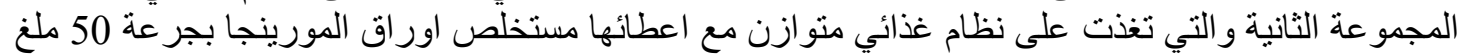

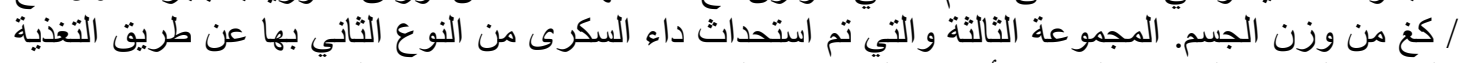

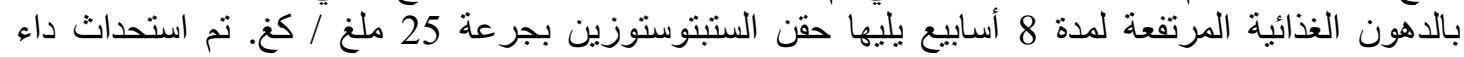

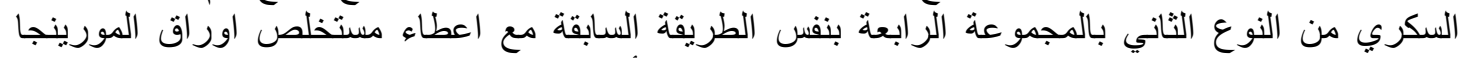

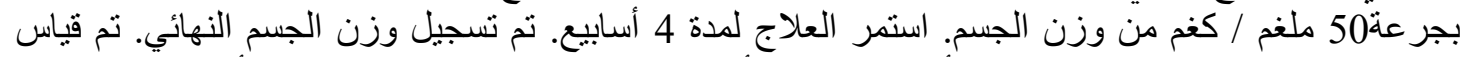

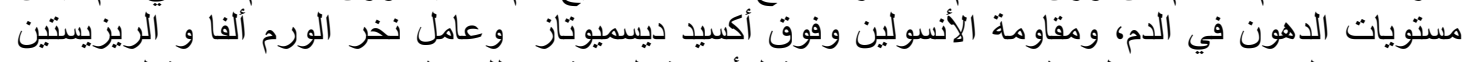

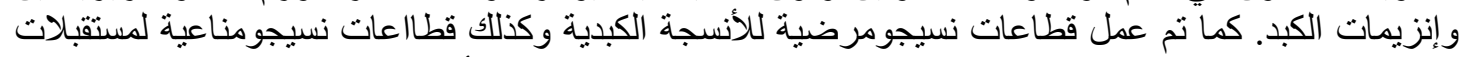

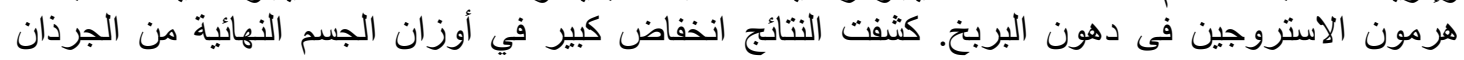

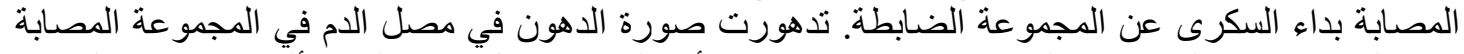

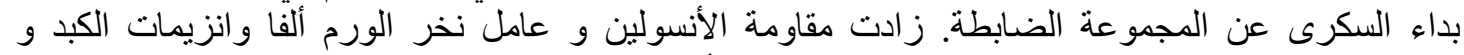

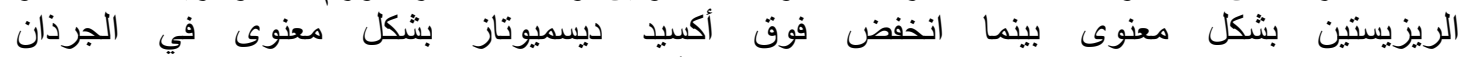

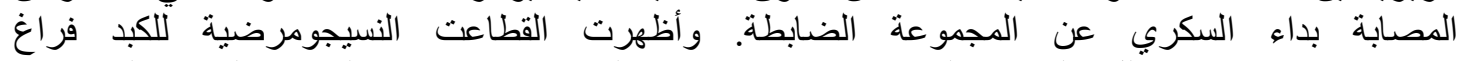

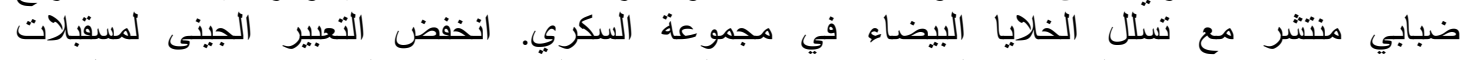

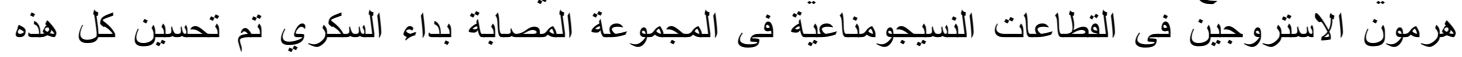

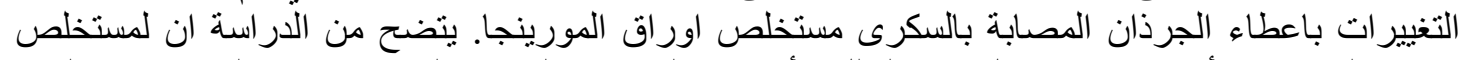

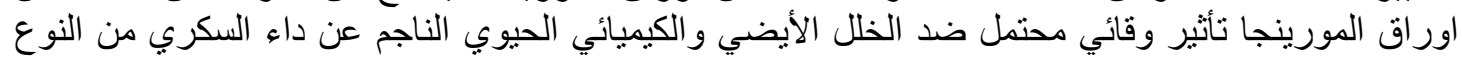

